\title{
EDITORIAL PREFAGE
}

It is ten years since the Journal of African Law started publication. The Editorial Committee of the Journal thought that it would be appropriate to mark the occasion by the publication of a special commemorative decennial number, which might afford an opportunity to contributors for a retrospective look at the evolution of African law in the decade, and give them a chance to express an opinion about the likely course of African legal development in the next decade.

We are delighted to be able to welcome such a distinguished galaxy of contributors to our pages, drawn from the ranks of those whom the Journal was established to serve. Mr. Justice Ollennu, the President of the International African Law Association, whose official organ this Journal is, contributes a Foreword which draws upon his wisdom and experience, not only as a leading judge and practitioner, but as an author of perceptive analyses of Ghana law (especially the laws of land tenure and succession), as a law reformer (through his presidency of governmental commissions for the reform of the law in Ghana) and as a legal educator at the University of Ghana Law Faculty and the Ghana Law School.

Chief Rotimi Williams, doyen of the Nigerian Bar, brings his very long experience of the realities of Nigerian law to bear on the question of how Nigerian law has moved and ought to move, since the end of the colonial period.

Another of our authors who typically combines the practical and the theoretical approaches to African law is the Hon. Haji Dr Noor Muhammad, who, after a distinguished career as Vice-President of the Somali Supreme Court in which he has made an important contribution to the development of Somali law, is now serving Somalia in another capacity, as legal adviser to the Prime Minister.

If we move to the more strictly academic side, the Dean of the Faculty of Law at the University of Khartoum, Zaki Mustafa, provides a fascinating sidelight on the continuing relationship between English and Sudanese law, and the problems of adapting a fundamentally literate law to the needs of a largely illiterate population. Professor M. Alliot, the Professor of African Law at the University of Paris, with his unrivalled knowledge of the legal problems of French-speaking Africa, considers one of Africa's most fundamental needs, that for unity, as it expresses itself in the legal domain; and puts forward some very interesting suggestionsmainly through systematic codification-for meeting them.

One of the main questions for consideration at such a turning point in African legal development is whether there have been fundamental changes both in the laws themselves and in the preoccupation of lawyers with them. Vol. I, No. I, contained articles on "Muslim marriages and the courts in East Africa" and on "The authority of English decisions in colonial courts", whilst among the cases noted was Maleksultan's case, which dealt with the recognition 
of Muslim marriages in Tanganyika and the internal conflict problems to which this may give rise. The present number, Vol. i I, No. 2, it is amusing to note, reports just two cases: one from the far west of Africa which concerns Muslim marriages and their relationship with statutory and Christian marriage; and one from central Africa which discusses the relevance of English decisions and doctrine in the interpretation of the Zambian Penal Code! That the Journal is not perpetually stuck with these two problems is sufficiently evidenced by our other contributions, which run the gamut of the statutory, religious and customary legal systems of Africa.

Naturally not all the hopes and intentions with which the Journal was launched have been fulfilled. In some cases, lack of resources have frustrated implementation; in others, there has been a change of interest or direction. But we have all tried to extend the Journal's range and coverage in ways which were not contemplated in 1957; the study of the problems of African legal education and the bridging of the legal gap between the civil law and common law worlds in Africa are two examples of this.

We are fortified both by the ready and learned contributions of our readers, and by the unique position in which the Journal still finds itself in the African law field, to persist in our attempt to meet the needs and interests of teacher, researcher, practitioner, judge, socialist scientist, and librarian who wish to know more, not only of the national legal systems with which they are in closest contact, but of those which operate in neighbouring African countries.

THE EDITOR 